\title{
How Novelty Arises from Fields of Experience
}

A Comparison Between W. James and A. N. Whitehead

Maria Regina Brioschi

\section{(2) OpenEdition}

\section{Journals}

Electronic version

URL: http://journals.openedition.org/ejpap/595

DOI: 10.4000/ejpap.595

ISSN: 2036-4091

Publisher

Associazione Pragma

\section{Electronic reference}

Maria Regina Brioschi, « How Novelty Arises from Fields of Experience », European Journal of Pragmatism and American Philosophy [Online], V-1 | 2013, Online since 16 July 2013, connection on 25 April 2019. URL : http://journals.openedition.org/ejpap/595 ; DOI : 10.4000/ejpap.595

This text was automatically generated on 25 April 2019

\section{(c) $(1) \odot$}

Author retains copyright and grants the European Journal of Pragmatism and American Philosophy right of first publication with the work simultaneously licensed under a Creative Commons AttributionNonCommercial-NoDerivatives 4.0 International License. 


\section{How Novelty Arises from Fields of Experience}

A Comparison Between W. James and A. N. Whitehead

Maria Regina Brioschi

\section{The "Re-coloration" of James, according to Whitehead}

1 Before understanding and comparing the authors' thoughts from the perspective of their conceptions of experience, it is necessary to clarify and explain what is their connection, from a historical-critical point of view. Indeed, the relationship subsisting between James and Whitehead has been noticed from the very outset by the critical scholarship on Whitehead, as is testified by the presence of articles that appeared before the author's death. ${ }^{1}$ Such concern is due not only to the fact that Whitehead inaugurates the properly speculative phase of his thought in $1924,{ }^{2}$ the same year in which he is called to teach at Harvard University, nor even simply to a peculiar affinity in terms of interests or temperament.

2 Granted that James is cited by Whitehead in the preface of his Process and Reality, alongside Bergson and Dewey, as evidence of his intellectual debt towards these authors, the place reserved for him in the peculiar history of philosophy outlined in Science and the Modern World holds a prominent relevance, which stands in need of clarification, if not of proper justification. By way of example, let us consider a passage from the aforementioned work:

It is an exaggeration to attribute a general change in a climate of thought to any one piece of writing, or to any one author. No doubt Descartes only expressed definitely and in decisive form what was already in the air of his period. Analogously, in attributing to William James the inauguration of a new stage in philosophy, we should be neglecting other influences of his time. But, admitting this, there still remains a certain fitness in contrasting his essay, Does Consciousness Exist?, published in 1904, with Descartes's Discourse on Method, published in 1637. 
James clears the stage of the old paraphernalia; or rather he entirely alters its lighting . (SMW: 143$)^{3}$ science, in this excerpt Whitehead equates the "genius" ${ }^{4}$ of the seventeenth century, Descartes, with James, correspondingly targeted as the genius of the nineteenth century. It is therefore inevitable to pose the following questions: why does Whitehead address James as the genius of the nineteenth century? Why does he "entirely alter the stage lighting "?

The first step towards an understanding of the momentous function of James, according to Whitehead, is that of getting a grasp of both the subject matter and the purpose of Science and the Modern World. In the introductory pages, Whitehead maintains that the thesis he means to develop in the text can find expression in the idea that the "quiet growth of science has practically recoloured our mentality" (SMW: 2). And that is not all, because these "modes of thought which in former times were exceptional are now broadly spread through the educated world" (SMW: 2). Consequently, this change can be traced of course in terms of scientific methodology and philosophical premises, but must be especially comprehended in terms of mentality, because - according to Whitehead "the new mentality is more important even than the new science and the new technology" (SMW: 2). The first aspect through which he addresses such a mentality consists in a renewed and constant attention for particular facts. The author highlights:

What I mean is just that slightest change of tone which yet makes all the difference. This is exactly illustrated by a sentence from a published letter of that adorable genius, William James. When he was finishing his great treatise on the Principles of Psychology, he wrote to his brother Henry James, "I have to forge every sentence in the teeth of irreducible and stubborn facts." (SMW: 2-3)

The change of tone is therefore determined by the primary interest accorded to stubborn facts. But by laying stress on this aspect, Whitehead does not mean so much as to become the champion of a vague and naïve emphasis on mere facts $^{5}$ as he does to invoke the same orientation attitude which James outlines well in What Pragmatism means, where he claims that pragmatism is that "attitude of looking away from first things, principles, 'categories,' supposed necessities; and of looking towards last things, fruits, consequences, facts" (WWJ1: 32).

6 Strictly speaking, for Whitehead this change can be easily clarified by the brief comparison between the results produced by Descartes's and James's thoughts. Indeed, on the one hand Whitehead claims that, in virtue of the clear-cut distinction between matter and consciousness worked out by Descartes, "after the close of the seventeenth century, science took charge of the materialistic nature, and philosophy took charge if the cogitating minds" (SMW: 145), and that this perpetration of such a rigid dualism has led to "unfortunate limitations of thought on both sides. Philosophy has ceased to claim its proper generality, and natural science is content with the narrow round of its methods" (FR: 50). On the other he observes that "we have now come to a critical period of the general reorganization of categories of scientific thought. Also sciences, such as psychology and physiology, are hovering on the edge of the crevasse separating science from philosophy" (FR: 50), and for Whitehead James is the most prominent champion of such a reorganization. ${ }^{6}$

7 As far as the change in mentality is concerned, we might say that the paradigm of scientific materialism has begun to fade away since the nineteenth century, so paving the way for an organicistic conception which, starting from the primacy accorded to

European Journal of Pragmatism and American Philosophy, V-1 | 2013 
experience, acknowledges that "the concrete fact, which is the organism, must be a complete expression of the character of a real occurrence. Such a displacement of scientific materialism, if it ever takes place, cannot fail to have important consequences in every field of thought" (SMW: 38-39).

From another point of view, if "the ancient world takes its stand upon the drama of the Universe, [and] the modern world upon the inward drama of the Soul" (SMW: 141), nowadays drama is represented by 'event,' conceived of as a primeval and primary unity of universe and soul. Thus, one might agree with whitehead in claiming that:

The materialistic starting point is from independently existing substances, matter and mind. The matter suffers modifications of its external relations of locomotion, and the mind suffers modifications of its contemplated objects. There are, in this materialistic theory, two sorts of independent substances, each qualified by their appropriate passions. The organic starting point is from the analysis of process as the realization of events disposed in an interlocked community. The event is the unit of things real. (SMW: 152-153) ${ }^{7}$

Thanks to such a swift journey throughout Whitehead's thought, it is now clearer why that 'adorable genius,' as he defines James, occupies such a central place in his historical and theoretical analysis. Having concluded this preliminary part, we might now safely venture ourselves into more specific aspects of the influence which James exerted on Whitehead.

\section{Comparing Philosophies: The Role of Reason and Experience}

If, as it has been shown so far, Whitehead's appreciation of James is undeniable, ${ }^{8}$ it will be now necessary to identify the specific elements of influence, and then proceed to the confrontation between the two authors with reference to the problem of novelty. ${ }^{9}$

11 First of all, from the point of view of both method and setting the authors have similar requirements, which can be grouped into three different and salient conceptual points, namely 1) The task and role of the philosophical praxis, in agreement with a properly antiintellectualistic instance; 2) The "prospective" (WWJ1: 53) and dynamic nature of reason (and hence of philosophy); 3) Empiricism and the absolute primacy of experience. 10

12 (1) For both authors the very first function of philosophy (or of the pragmatic method) consists in offering an instrument able to unveil and sort out those controversies of the abstract thought, which depend on misplaced assumptions and metaphysical premises, by way of reduction or reference to the field of experience. Just as - Sini claims - "more than to 're-solve' problems and to inspire definite beliefs, the pragmatic maxim helps to 'dissolve,' to show that they are 'false problems"' (Sini 2000: 15), ${ }^{11}$ in the same way Whitehead maintains that the first function of philosophy is to be a "critic of abstractions" (SMW: 88), throughout a reference to experience as the utmost concretum: in fact, on the author's view, "the elucidation of immediate experience is the sole justification for any thought" (PR: 4), whereas thought, qua abstract, always runs the risk of getting impaired by the so called "fallacy of misplaced concreteness" (SMW: 52). All the same, a meaningful difference ought to be considered with respect to this resort to experience, in an anti-intellectual perspective. Indeed, for Whitehead the appeal to facts has a derivative intent, while for James it has an applicative one. In other words, the 
unveiling of preconceived theses occurs, in the case of Whitehead, through the referral of a given concept to the field of the ex- perience from which it derives its origin; whereas, in the case of James, it occurs through the confrontation with the consequences which the concept at issue might bring about. As James states: "The pragmatic method is primarily a method of settling metaphysical disputes that otherwise might be interminable. [...] The pragmatic method in such cases is to try to interpret each notion by tracing its respective practical consequences. What the difference would it practically make to any one if this notion rather than that notion were true?" (WWJ1: 28).

(2) Secondly, in order to understand the specific nature of this philosophical attitude, it is necessary, on the one hand, to catch a glimpse of the methodological perspective adopted by both authors and, on the other, to understand the possibilities and the nature they acknowledge to reason. In this respect, it might be useful to oppose the thought of James and Whitehead to the rationalistic tendencies proper to traditional philosophy. As James himself suggests:

The essential contrast is that for rationalism reality is ready-made and complete from all eternity, while for pragmatism it is still in the makings and awaits part of its complexion from the future. On the one side the universe is absolutely secure, on the other it is still pursuing its ad- ventures (WWJ1: 123).

As James stresses in a more articulated way in his A Pluralistic Universe - if, qua rationalists, "you have broken the reality into concepts you never can reconstruct it in its wholeness. Out of no amount of discreteness can you manufacture the concrete" (WWJ4: 116). On the contrary - and this is exactly his pragmatic invitation - one should pose oneself "in the making by a stroke of intuitive sympathy with the thing [...]. Philosophy should seek this kind of living understanding of the movement of reality, not follow science in vainly patching together fragments of its dead results" (WWJ4: 117-18).

If the echo of Bergson resounds in such an invitation, it is nevertheless true that the immediacy and sympathy, indicated as a way towards an effective knowledge of experience, do not correspond to a form of intuitionism able to pave the way for the irrational and to distrusts reason in its power to positively grasp the items internal to "the living, moving, active thickness of the real" (WWJ4: 116). Rather, it is a matter of an opening and an understanding that differ from the retrospective analysis to which we use to associate the employment and the function of reason. What are therefore the possibilities and the modalities proper to the philosophical progression here introduced, as well as to reason - understood as its tool? First and foremost, as James points out in Pragmatism by criticizing Spencer's stance, philosophy is not simply retrospective: "philosophy is prospective also, and, after finding what the world has been and done, and yielded, still asks the further question "what does the world promise?"' (WWJ1: 53). ${ }^{12}$ What clearly re-emerges here is that dimension of becoming (and properly of the future) situated at the core of the distinctive concreteness of the real movement described above. This is properly the direction pursued by radical empiricism, as James specifies in his Essays in Radical Empiricism:

Understanding backwards is, it must be confessed, a very frequent weakness of philosophers, both of the rationalistic and of the ordinary empiricist type. Radical empiricism alone insists on understanding forwards also, and refuses to substitute static concepts of the understanding for transitions in our moving life. A logic similar to that which my critic seems to employ here should, it seems to me, forbid him to say that our present is, while present, directed towards our future. (WWJ3: 121) ${ }^{13}$ 
16 implications of a given idea in order to assess it. The kind of world it takes issue with is a world being constantly in fieri; therefore, its investigation is bent onwards with respect to the same concepts on which philosophy usually hinges. The function of philosophy - and that of reason (pragmatically conceived) - emerges into light while frontally facing change and becoming, without exhausting itself in its own distinctive retrospective analytic. What does philosophy consist of, then? How can it be described? With regard to this, it will be useful to make use of some passage of Whitehead, extremely akin to the position just expounded and taken from a short text published in 1929: Function of Reason. ${ }^{14}$ In this work, which a substantial part of the Whiteheadian scholarship has not hesitated to define "the most straightforward, and in many ways the most suggestive and delightful of Whitehead's books" (Emmett 1966: 11), the author takes into account the concept of reason without confining himself to analyzing it in terms of the essence of the human being, but rather analyzing it as a "cosmic force," 15 that is, as "the self-discipline of the originative element in history" (FR: i), whose whose function is to "promote the art of life" (FR: 2). ${ }^{16}$ Still, moving beyond the specific argument of the text, in which the cosmological point of view coincides with the phenomenological-experiential one, I shall focus on a single aspect of such a work: the nexus of reason with the dimension of the future.

In Symbolism (1927) the author introduced such a "pragmatic appeal to the future" (S: 31) as a necessary aspect of philosophical investigation, remarkably, in Function of Reason this aspect receives further attention. In Whitehead's view, reason is not "a passively receptive substance" (S: 32 ), its value is of a "pragmatic, or even instrumental" ${ }^{17}$ kind: it is not an object, because it always proves to be an essential minimal dynamic, an irreducible one. This is why it is more appropriate to study it from the perspective of its function, and it is just from the latter that Whitehead starts to rediscover and identify reason as "the organ of emphasis upon novelty" (FR: 15). The author maintains that, without such an organ, the one which proves able to capture and highlight novelty, there would be nothing but mere repetition (that is, the sole thing to which rationalism can aspire), and this would turn out to be nothing but the expression of a "stealthy inevitableness" (FR: i), disowned by both the same progressing activity of reason and by experience. In other words, at the cosmological level, whitehead lays stress on the idea that nothing in the universe stands unaltered, ${ }^{18}$ not even the inorganic matter, whereas what is to be acknowledged is a "tendency upwards, in a contrary direction to the aspect of physical decay. In our experience we find appetition, effecting a finale causation toward ideal ends which lie outside the mere physical tendency" (FR: 72), at whose peak is located reason which, in its turn, even at its minimal levels, consists properly in "its judgments upon flashes of novelty, of novelty in immediate realization and of novelty which is relevant to appetition" (FR: 15).

Far from exhausting the issue in Whitehead's thought, what emerges here equally and with transparency is the same need manifested by James, i.e. that to connect - and almost indentify - the proper object of reason, and therefore of philosophy (which uses reason as its distinctive instrument), with the becoming, that is, with the new. As Deleuze has sharply stressed, for Whitehead "the best of all worlds is not the one that reproduces the eternal, but the one in which new creations are produced, the one endowed with a capacity for innovation or creativity" (Deleuze 1993: 89).

19 In a nutshell, then, this short text gives expression to both (a) a closeness, on Whitehead's part, to conception of reason entertained by Pragmatism, and (b) its "prospective" nature 
- to use James's terminology - which goes over and above the regressive conceptual analysis proper to the rationalistic view. To better understand the aspects that have emerged here, one cannot help analyzing, eventually and specifically, the peculiar concept of experience and the reasons of the central role it plays within the philosophical efforts made by the examined authors.

(3) Without intending to go over the many contributions offered on the confrontation between empiricism and the concept of experience in James a Whitehead, a recovery of this theme is required, besides the urgency to better understand the prospective role of reason by bringing to light the specific experiential elements on which this hinges, to show the essential elements which underpin and make the respective cosmologies possible.

21 For better clarity, I therefore make a distinction between the method of James's radical empiricism - as well as Whitehead's pan-experientialism ${ }^{19}$ - and the conception of experience subsisting in both authors.

22 James and Whitehead equally feel the need to pose experience as the absolute and original ground, antecedent to any possible subject-object, knower-known, mind-body distinction; suffice it to say that, in his Modes of Thought, Whitehead draws James close to Plato, Aristotle and Leibniz by highlighting the peculiarly modern style of his thought, which he precisely characterizes as a "protest against the dismissal of experience in the interest of system" (MT: 4). Hence, for both thinkers, such a need immediately becomes an absolutely unavoidable methodological character.

(3a) As far as James is concerned, the phrase 'radical empiricism' is nothing but a possible interpretation of Pragmatism. As he sharply states, once again, in his Essays in Radical Empiricism:

The way of handling things I speak of, is, as you already will have suspected, that known sometimes as the pragmatic method, sometimes as humanism, sometimes as Deweyism, and in France, by some of the disciples of Bergson, as the Philosophie nouvelle. [...] I myself have given the name of 'radical empiricism' to that version of the tendency in question which I prefer. (WWJ3: 79-80)

Radical Empiricism opposes itself to rationalism and its absolutistic ${ }^{20}$ and monistic ${ }^{21}$ tendencies as much as to classical empiricism, since Radical Empiricism rejects their conception of 'pure datum,' of a punctual, atomic and unrelated one, by claiming the actuality of the relations, which are and can be properly experienced. The peculiar character of this approach resides in its referring any of its claims to the field of experience, the latter understood as a dimension to which relations themselves belong, being in this respect original and not derived. As James points out in his A World of Pure Experience:

To be radical, an empiricism must neither admit into its constructions any element that is not directly experienced, nor exclude from them any element that is directly experienced. For such a philosophy, the relations that connect experiences must themselves be experienced relations, and any kind of relation experienced must be accounted as 'real' as anything else in the system. Elements may indeed be redistributed, the original placing of things getting corrected, but a real place must be found for every kind of thing experienced, whether term or relation, in the final philosophic arrangement. (WWJ3: 22)

It is therefore possible to understand how novelty, which underpins the pragmatic method and sets it against all the previous "empiricisms," relies on a radically different concept of experience. Namely, an experience immediate but not punctual, structured but 
not defined, articulated but always dynamic, opened up, granted that - as the author claims- "our fields of experience have no more definite boundaries than have our fields of view. Both are fringed forever by a more that continuously supersedes them as life proceeds" (WWJ3: 35).

With respect to this, however, it might legitimately be asked whether and in which way the conception of experience as structured and continuous - the one that has just been sketched out - can coexist in James's reflection with the so called 'pure experience,' a constant reminder of his whole radical empiricism. If the time at which such theses were expressed cannot support the hypothesis of a meaningful chance of thought, given that they both refer not only to the same span of years, but even to the same essays, can we attribute such a fluctuation to an ultimate fundamental indecision? How else can such an (apparent?) opposition be explained?

In order to answer these questions we should carefully reconsider the same passages in which James displays the concept of pure experience. By way of example, let us consider the following definition, occurring in Essays in Radical Empiricism:

'Pure experience' is the name which I gave to the immediate flux of life which furnishes the material to our later reflection with its conceptual categories. Only new-born babes, or men in semicoma from sleep, drugs, illnesses, or blows, may be assumed to have an experience pure in the literal sense of a that which is not yet any definite what, tho ready to be all sorts of whats. (WWJ3: 46)

According to what the passage reports, it would seem that 'pure experience' can be shown only in a negative fashion, uniquely by subtraction from our most daily experience: when can we actually claim that we are making experience of a pure 'that'? What is claimed here is not certainly a minor outcome, granted that James re-assesses the field of experience by broadening it, in relation to the exclusively epistemological borders within which it had been situated from Kant onwards, ${ }^{22}$ but this still does not help us to understand the compresence of two elements apparently so distant from each other. Or, better stated, "this is not his unique merit: he offers a positive characterization, through which experience is caught as a process, or as a stream [...] that precedes any theoretical and metaphysical differentiation. Experience must be understood as a development, as a process. It represents a complex set of occurrences which forge the structure of the respective original process" (Schrag 1969: 489). ${ }^{23}$ For pure experience is, as stated by the last of James's quotations, an "immediate flux of life," in which its purity cannot be identified with something absolutely indistinct: ${ }^{24}$ within it, "the immediately experienced conjunctive relations are as real as anything else" (WWJ3:45-46). In other words, according to James "knowledge of sensible realities thus comes to life inside the tissue of experience. It is made; and made by relations that unroll themselves in time" (WWJ3: 29). ${ }^{25}$ We can then affirm that James holds experience to be a process, ${ }^{26}$ and although this does not deprive experience itself of the character of purity he attaches to it. James himself asserts:

According to my view, experience as a whole is a process in time, whereby innumerable par- ticular terms lapse and are superseded by others that follow upon them by transitions which, whether disjunctive or conjunctive in content, are themselves experiences, and must in gen- eral be accounted at least as real as the terms which they relate. (WWJ: 31-32)

It is not therefore necessary to alternatively opt for a concept of 'pure' experience or of 'structured' experience, on condition that we spell out the meaning of those terms. In fact, there is a first distinction which we might detect between that and what, pure 
experience and determined experience, which is unequivocally stated and that - in its turn - is nevertheless to be understood as analysis and de-composition of a unique and unitary moment. ${ }^{27}$ Then there is a second distinction, one which, although not definite in James's account, is still present and is necessary to lay down in order to understand both his concept of experience and his peculiar radical empiricism, alongside the pluralism which on such an empiricism relies. Such a necessity is determined by our thought's habits, which lead us 'naturally' to conceive of experience in an atomic, punctual and unrelated sense, whereas it is just this traditional mode of thought, linked to classical empiricism, that the philosophy of James means to dismiss. The distinction, then, is that between this punctual concept of experience and the concept of a continuous and relationally informed experience, the latter type being the one endorsed by James. On such a distinction emerges a profound affinity with Whitehead's speculation, which deepens and systematises some of the convictions here expressed. ${ }^{28}$

(3b) Whitehead comes close to an analogous empiricist perspective in those works which have been regarded essays of epistemology or "pre-speculative philosophy" (Lowe 1990: 92), by displaying the same insistence on the relational character of the experiential flux. Although in his thought any reference to "pure experience" 29 is absent, in the centrality attached to the concept of experience he points out the experience's characteristics as follows: i) unitariness; ii) extensionality; iii) relatedness; iv) processuality. ${ }^{30}$ Thus, if the author affirms, as he does in The Anatomy of Some Scientific Ideas (1917), that "we conceive ourselves each experiencing a complete time-flux (or stream) of sense-presentation [...] distinguishable into parts" (AE: 128-129), such a flux exhibits itself, just qua flux, both as (i) unicum and as (ii) extended. For it represents the "unit of things real" (SMW: 152), but its nature is not punctual, given that - qua activity of flowing - it is not circumscribable to an isolated spatio-temporal point, ${ }^{31}$ but is rather to be understood as a "continuum" (AE: 109). Moreover (iii) such a flowing is for whitehead always structured, ${ }^{32}$ and its distinctive structure is given by the dynamic interrelation between events, which constitute in some respect the "ultimate substance of nature" (CN: 19). Namely, that an event is the "ultimate substance of nature» not in the same sense as the Aristotelian upocheimenon, but as "this unit factor, retaining in itself the passage of nature" (CN: 75). Furthermore, every event is in relation with the others and with the totality of events, and this "relatedness does not just happen, but is the skeleton of an active process of becoming which [...] is both a complex of objects and an outcome of other becomings" (Lowe 1962: 202). ${ }^{33}$ (iv) Experience, then, presents itself as a "dynamic totality," ${ }^{34}$ unitary but not monolithic, united but not stable, always open and in a state of becoming, in which the events that compose itself are themselves forms of becoming. It is starting from an experience so conceived that Whitehead's mature reflection will mould itself, that is, starting from "the analysis of process as the realization of events disposed in an interlocked community" (SMW: 152). Finally, just as James's pure experience used to overcome the classical oppositions of epistemological type (subject/object; knower/ known) in the same way "the metaphysical conception championed in Process and Reality and in the coeval works is to be characterized as ontology of integral experience, irreducible to the model grounded in the opposition between subject and object" (Vanzago 2001: 310). ${ }^{35}$

31 Such an "ontology of integral experience" can be translated, from a strictly methodological point of view, not so much into a form of empiricism as into one of "panexperientialism." ${ }^{36}$ Equipped with such a type of setting, Whitehead radicalizes some of 
the most modern claims, just as James's pragmatic one, by trying nevertheless to systematize them within a coherent methodological construction. For in Process and Reality the author sets up an ontology which is no longer grounded in the concept of 'substance,' but rather in that of 'event,' one which leads him to conceive a radically different universe, whose processuality and becoming are not derivative and accidental traits, but represent its original ground.

Just as the described experience, even if it is a continuum, reveals itself as a plurality of reciprocally interlocked events, in the same way Whitehead's universe is the compound of all the actual entities, "the final real things, of which the world is made up" (PR: 18). The word 'entity' is here taken up in the same sense that James uses in Does Consciousness Exist? , by denying conscience itself the 'entity status.' As James points out in a letter addressed to Peirce:

As for what entity may mean in general I know not, except it be some imperceptible kind of being. In my article [Does Consciousness Exist?] it meant a constituent principle of all experience, as contrasted with a certain function or relation between particular parts of experience. The distinction seems to me plain enough. (CWJ10: 480) ${ }^{37}$

If consciousness is regarded by both authors as a function of experience, actual entities are therefore its constitutive principle or, in other terms, the dynamic self-creating unities at the basis of the universe. They do not refer, however, to any sort of substance, within the borders of experience itself, as is revealed by the definition offered in the first pages of Process and Reality: "The how an actual entity becomes constitutes what that actual entity is; so that the two descriptions of an actual entity are not independent. Its 'being' is constituted by its 'becoming.' This is the 'principle of process"' (PR: 23). In other words, on Whitehead's view, an actual entity is:

An act of experience. The authority of William James can be quoted in support of this conclusion. He writes: "Either your experience is of no content, of no change, or it is of a perceptible amount of content or change. Your acquaintance with reality grows literally by buds or drops of perception. Intellectually and on reflection you can divide these into components, but as immediately given, they come totally or not at all." (PR: 68)

Thus, the phrase 'actual entity,' as indicated by the quote above, shows some affinities, not simply supposed, but even explicitly expressed, with James's thought. As evidence of this, for example, these are properly defined by Whitehead as "drops of experience, complex and interdependent" (PR: 18).

From such a rapid survey one can infer that, from the pre-eminence methodologically accorded to experience and the widening of that concept, both authors take a sui generis pluralistic stance. For example, in the metaphysical-cosmological context James and Whitehead are inclined to describe the universe as continuous and at the same time discontinuous, and they identify its ground with drops of experience, according to the former, or with actual entities, according to latter. In both cases, we are faced with a paradox: experience, the only field and horizon of philosophical speculation, reveals itself as a profound unity, but the cosmology which derives from it is of pluralist order. More specifically, the paradox arises from the fact that, starting from a methodological immanentistic assumption which in the one case takes the shape of radical empiricism and in the other that of pan-experientialism, the thinkers at issue develop a "monadic theory" of experience, one which coexists with a "pluralistic metaphysics." ${ }^{19}$ does it have to cope with and what kind of problems are those to which it tries to offer a 
response? In order to clarify which answers are offered by the authors with regard to the issue, it will be useful to face the problem of novelty, a theme to which the present work will now direct its critical attention.

\section{Between Experience and Pluralism: The Emergence of Novelty}

As I have anticipated, pluralism is one of the elements of affinity between the two philosophers. According to Lowe, it should even be considered as "the subject of the most obvious kinship between Whitehead and William James" (Lowe 1941a: 113). Still, thus far, critical scholarship has never fully explored the view of the two authors in relation to the theme of novelty, which figures not only among the objects of their speculative efforts, but also and properly at the center of the delineation of a pluralistic universe.

In order to note the attention accorded by the authors to this problem suffice it to think that James devotes to the theme of novelty the last five chapters of his Some Problems of Philosophy, and that the ultimate of the metaphysical system outlined in Process and Reality is 'creativity,' which is defined by the author himself as "principle of novelty" (PR: 21). In other words, we might therefore say that the whole cosmology of the Whiteheadian masterpiece presupposes and testifies to this phenomenon of novelty, so much that Whitehead can affirm that, in its wholeness, "the universe is a creative advance into novelty" (PR: 222)..$^{40}$

In this context, then, far from considering in an exhaustive manner the problem and its genesis in the reflection of the two authors, I shall confine myself to indicating those aspects of the problem that are principally connected to the determination of a pluralistic universe, that is, to showing those elements which prove helpful to respond to the questions of the last paragraph. Let us therefore try to put the two forms of pluralism into perspective.

If in the Essays in Radical Empiricism James claims that his philosophy "harmonizes best with a radical pluralism, with novelty and indeterminism" (WWJ3: 44), such a possible association is to be connected with the particular disjunctive-conjunctive character of experience, already highlighted in the analyses, which is now taken up and applied to the features of all the universe. As James himself declares in a passage of Pragmatism:

These forms of conjunction are as much parts of the tissue of experience as are the terms which they connect; and it is a great pragmatic achievement for recent idealism to have made the world hang together in these directly representable ways instead of drawing its unity from the 'inherence' of its parts - whatever that may mean - in an unimaginable principle behind the scenes. 'The world is one,' therefore, just so far as we experience it to be concatenated, one by as many definite conjunctions as appear. But then also not one by just as many definite dis junctions as we find. The oneness and the manyness of it thus obtain in respects which can be separately named. It is neither a universe pure and simple nor a multiverse pure and simple. (WWJ1: 72-73)

41 It is therefore starting from the nexūs present in experience that the unity and plurality of the universe are affirmed. As the author points out in A Pluralistic Universe,

Our 'multiverse' still makes a 'universe'; for every part, tho it may not be in actual or immediate connexion, is nevertheless in some possible or mediated connexion, with every other part however remote, through the fact that each part hangs together with its very next neighbors in inextricable interfusion. The type of union, 
it is true, is different here from the monistic type of alleinheit. It is not a universal co-implication, or integration of all things durcheinander. It is what I call the strungalong type, the type of continuity, contiguity, or concatenation [...] the synechistic type. (WWJ4: 146-47)

Thus James's pluralistic universe does not fight against any form of 'continuism'; it exclusively opposes monism. What is, then, the difference with monism? Where can the evidence for this difference be more forcefully shown? According to the author, "towards this issue, of the reality or unreality of the novelty that appears, the difference between monism and pluralism seems to converge" (WWJ7: 74-75). According to James, the rationalist theory, which he associates to monism, ${ }^{41}$ by offering a "rounded-in view of the whole of things, a closed system of kinds" (WWJ7: 55) has operated - as a matter of fact an a priori exclusion of the possibility of a novelty, whereas pluralism dares to pose the following question once again: "In what manner does new being come? [...] Is it original?" (WWJ7: 75), or, again: "When perceptible amounts of new phenomenal being come to birth, must we hold them to be in all points predetermined and necessary outgrowths of the Being already there, or shall we rather admit the possibility that originality may thus instil itself into reality?" (WWJ7: 76).

43 By making a stand with respect to these questions, the theory of pluralism departs from monism. In fact, in tune with his pragmatic postulates, James answers to this question by drawing on the field of experience:

We do, in fact, experience perceptual novelties all the while. Our perceptual experience overlaps our conceptual reason: the that transcends the why. So the common-sense view of life, as something really dramatic, with work done, and things decided here and now, is acceptable to pluralism. (WWJ7: 73) ${ }^{42}$

We find two remarkable aspects here: (a) on the one hand, James confirms a distance between the purely conceptual and the experiential ground; (b) on the other hand, in the "ulteriority" of sense-experience he detects that possibility of novelty which rationalists and monists cannot do anything but deny.

Notably, as far as the first aspect is concerned, the author claims that "whatever actual novelty the future may contain (and the singularity and individuality of each moment makes it novel) escapes conceptual treatment altogether. Properly speaking, concepts are post-mortem preparations, sufficient only for retrospective understanding" (WWJ7: 54-55); as for the second aspect, instead, on James's view "the percepts are singulars that change incessantly and never return exactly as they were before. This brings an element of concrete novelty into our experience" (WWJ7: 54). In particular, James reports his personal experience on the matter, psychological and also non-psychological, in order to testify to both this hiatus between understanding and perceptual experience and this irreducibility of novelty, which would witness its original being. As James in fact argues:

Psychologically considered, our experiences resist conceptual reduction [...]. Biography is the concrete form in which all that is is immediately given; the perceptual flux is the authentic stuff of each of our biographies, and yields a perfect effervescence of novelty all the time. New men and women, books, accidents, events, inventions, enterprises, burst unceasingly upon the world. It is vain to resolve these into ancient elements, or to say that they belong to ancient kinds, so long as no one of them in its full individuality ever was here before or will ever come again. Men of science and philosophy, the moment they forget their theoretic abstractions, live in their biographies as much as any one else. (WWJ7: 78)

Therefore, novelty is for James inherent in and emerging from that "perceptual flux" which represents the "substance of biography" proper to each of us. A flux which, on the one 
hand, consistently with the exposition of the concept of experience, is "the throughandthrough union of adjacent minima of experience, of the confluence of every passing moment of concretely felt experience with its immediately next neighbors" (WWJ4: 147), ${ }^{43}$ but which, on the other, represents a continuous space of novelty in virtue of the disjunctive relations in which its constitutive parts stand. As a consequence, sustaining a pluralistic universe coincides exactly with the possibility of affirming an "additive universe" (WWJ7: 103), to use the author's own words, which echo the aforementioned ones pronounced by Whitehead. For, on this point of view, one might support the view that the two thinkers hold the same thesis: that they both describe the same universe, that they both champion the same "creative advance of the world" (PR: 345), to use Whitehead's terminology.

Retrieving the questions from which this final part of the present work has begun, we might now understand how, as far as James is concerned, there is no incongruence between the immanentism proper to the radical empiricism and the pluralism sustained in a speculative-cosmological perspective.

Such a possibility of understanding is given by that broadening of the field of experience, continuous and relationally informed, which exhibits itself not only as a wholeness of irreducible elements, but also as a wholeness in which it becomes possible to think of the emergence itself of irreducibility, of novelty. To summarise, we might otherwise say that such a flux and such a novelty are for James effective, in that we can make experience of them. On the other side, however, what remains in the author's reflection is a discrepancy consisting in the idea that, if it is real and pragmatically correct to affirm such a flux and novelty, it is by contrast impossible to admit any conceptual understanding of them. For the author maintains that "conception knows no way of explaining save by deducing the identical from the identical, so if the world is to be conceptually rationalized no novelty can really come" (WWJ7: 78), and it is precisely on this point that Whitehead would utterly dissent from James.

In fact, Process and Reality can be read as an attempt to rationalize what James gives up. Whitehead himself, in a letter addressed to Hartshorne, having indicated the bright minded American philosopher as a "sensitive genius" states that, on his view, he was nevertheless "weak on Rationalization." ${ }^{44}$ In order to better understand such a claim, let us consider that, in his writings, on several occasions whitehead distances himself both from those philosophers that perpetrate the dogmatic error by sustaining the "illusiveness and relative unreality of the temporal world," both from those that, like Bergson, maintain "that the intellect necessarily falsifies the notion of process." ${ }^{45}$ In the same way, even James - to his eyes - might be included within these philosophers who, even without coming to conceive of intellect as 'falsifying,' identify any comprehensive and conceptual advancing of the intellect with the one proper to rationalism. On Whitehead's view, instead, there is a third way, a properly conceptual one, one consisting in the attempt not only to admit novelty, but also to understand and explain it. The central point to be acknowledged for the author is, as the aforementioned passage indicates, the concept of process. Its philosophical originality resides precisely in the attempt to rethink such a concept throughout the peculiar form of pan-experientialism. A process which does not set up a dialectic movement, as the one of Hegelian kind, one which, by way of Aufhebung, comes to embrace everything into one single reality, but rather a process that is constant advancement of novelty ${ }^{46}$ and, at the same time, affirmation of the irreducibility of its components. 
If we can claim, after the survey that has been conducted, that the main point of contact between the two authors is that of pluralism, now on the basis of acknowledgement of a new status for experience we should make a final point, noticing that their intellectual journeys depart from each other far before the pluralistic conception outlined in their mature works. For if pluralism is shared, the difference is to be identified in the conception of experience, of its unity and modeling.

51 Eventually, on James's view, the unity (plural and infinite) of experience is given and experienced, but is ultimately impossible to grasp conceptually, whereas, on Whitehead's view, one can approach it through the concept of 'process.' Whitehead, in other words, in the attempt to understand that flux which James takes to be real but not conceptualizable, after identifying it as a process tries to set up a true metaphysics of the process, of a becoming which does not presuppose any substratum and does not involve any identity posed as final term. The difficulty of its work actually resides in this aspect: the attempt to rethink the cosmos in terms of becoming, process, without reference to any creatio ex nihilo ${ }^{47}$ or appeal to whatever kind of transcendence. As the author claims:

There are two current doctrines as to this process. One is that of the external Creator, eliciting this final togetherness out of nothing. The other doctrine is that it is a metaphysical principle belonging to the nature of things, that there is nothing in the Universe other than instances of this passage and components of these instances. Let this latter doctrine be adopted. Then the word Creativity expresses the notion that each event is a process issuing in novelty. (AI: 236)

To conclude, on this perspective, novelty in Whitehead is documented, justified and made possible by the becoming of the actual entities - every actual entity is a "self-creating creature" (PR: 85) - and from their multifarious, open relationships, which make up the unicum of the universe. For James, instead, novelty is simply admitted, stated and acknowledged in its maximally concrete value. It is maybe for this reason that Whitehead can be indicated as a sui generis forerunner of emergentism, ${ }^{48}$ even though the nexus between emergentism and pluralism would require a new, further in-depth examination, bearing on those "fields of experience" (WWJ3: 35) to which, according to different accents, James and Whitehead have always appealed.

\section{BIBLIOGRAPHY}

ABBAGNANo N., (1961), "Whitehead e il concetto della ragione," Revue Internationale de Philosophie, 56-57, 204-15.

BONFANTINI M.A., (1972), Introduzione a Whitehead, Bari, Laterza.

CAFARO F., (1963), “Nota," in A. N. Whitehead, La funzione della ragione, ed. by F. Cafaro, Firenze, La Nuova Italia.

COBB J. B., \& D. R. GRIFFIN, (1977), Mind in Nature. Essays on the Interface of Science and Philosophy, Washington D.C., University Press of America.

DeLEUZE G., (1988/1993), Le Pli, Paris, Les éditions de Minuit; The Fold, London, The Athlone Press. 
EISENDRATH C. R., (1971), The Unifying Moment. The Psychological Philosophy of William James and Alfred North Whitehead, Cambridge, Harvard University Press.

EMMET D., (1966), Whitehead's Philosophy of Organism, New York, St. Martin's Press.

FIELD R. W., (1983), “William James and the Epochal Theory of Time,” Process Studies, 13, 4, 260-74.

FORD M. P., (1982), William James's Philosophy - A New Perspective, Amherst, University of Massachusetts Press.

FORD L. S., (1983), “An Alternative to Creatio ex Nihilo,” Religious Studies, 19, 2, 205-213.

GRIFFIN D. R., (2007), Whitehead's Radically Different Postmodern Philosophy: an Argument for Its Contemporary Relevance, Albany, State University of New York Press.

HARTSHORNE C., (1972), Whitehead's Philosophy - Selected Essays, Lincoln, University of Nebraska Press.

JAMES W., (1975-1988), The Complete Works of William James, 19 vols., ed. by Frederick H. Burkhardt, Cambridge, Harvard University Press [WWJ].

JAMES W., (1992-2004), The Correspondence of William James, ed. by I. K. Skrupskelis \& E. M. Berkeley, Charlottesville, University of Virginia Press [CWJ].

LOWE V., (1941a), "William James and Whitehead's Doctrine of Prehensions," The Journal of Philosophy, 38, 5, 113-26.

LOWE V., (1941b), “The Development of Whitehead's Philosophy,” in P. A. Schilpp (ed.), The Philosophy of Alfred N. Whitehead, New York, Tudor Publishing Company, 17-124.

LOWE V., (1949), “The Influence of Bergson, James and Alexander on Whitehead," Journal of History of Ideas, X, 2, 267-96.

LOWE V., (1962), Understanding Whitehead, Baltimore, John Hopkins University Press.

LoWE V., (1990), Alfred North Whitehead: The Man and His Work. Vol. II (1910-1947), Baltimore, John Hopkins University Press.

METZ R., (1938), A Hundred Years of British Philosophy, New York, Macmillan.

RoVATTI P. A., (1969), La dialettica del processo, Milano, Il Saggiatore.

schilpP P. A. (ed.), (1941), The Philosophy of Alfred N. Whitehead, New York, Tudor Publishing Company.

SCHRAG C. O., (1969), "Struktur der Erfahrung in der Philosophie von James und Whitehead," Zeitschrift für philosophische Forschung, 23, 4, 479-94.

SINCLAIR S., (2009), “William James as American Plato?," William James Studies, 4, 111-29.

SINI C., (2000), "Presentazione," in C. S. Peirce/W. James, Che cos'è il pragmatismo?, ed. by

F. Vimercati, Milano, Jaca Book.

SOELCH D., (2011), “From Consistency to Coherence - Whitehead's Transformation of James's Epistemic Conservatism," European Journal of Pragmatism and American Philosophy, 1, 3, 86-100.

STENNER P., (2011), "James and Whitehead: Assemblage and Systematization of a Deeply Empiricist Mosaic Philosophy," European Journal of Pragmatism and American Philosophy, 1, 3, 101-30.

TEIXEIRA M.T., (2011), "The Stream of Consciousness and the Epochal Theory of Time," European Journal of Pragmatism and American Philosophy, 1, 3, 131-45. 
VANZAGO L., (2001), Modi del tempo: simultaneità, processualità, relazionalità tra Whitehead e MerleauPonty, Milano, Mimesis.

WAHL J., (1932), Vers le concret. Études d'histoire de la philosophie contemporaine, Paris, Vrin.

WEBER M., (2002), “Whitehead's Reading of James and Its Context (Part One)," Streams of William

James, 4, 1, 18-22.

WEBER M., (2003), “Whitehead's Reading of James and Its Context (Part Two),” Streams of William

James, 5, 3, 26-31.

WEBER M., (2011), Whitehead's Pancreativism: Jamesian Applications, Frankfurt/Paris, Ontos Verlag.

WHITEHEAD A. N., (1919/1924), An Enquiry concerning the Principles of Natural Knowledge, Cambridge, Cambridge University Press.

WHITEHEAD A. N., (1920), The Concept of Nature, Cambridge, Cambridge University Press [CN].

WHITEHEAD A. N., (1925), Science and the Modern World, Cambridge, Cambridge University Press

[SMW].

WHITEHEAD A. N., (1927), Symbolism, Its Meaning and Effect, New York, Macmillan [S]

WhiteHEAd A. N., (1929a/1979), Process and Reality. An Essay in Cosmology, New York, Macmillan; corrected edition by D. R. Griffin and D. W. Sherburne, New York, The Free Press [PR].

Whitehead A. N., (1929b), Function of Reason, Princeton, Princeton University Press [FR].

WHITEHEAD A. N., (1929c), The Aims of Education and Other Essays, New York, Macmillan [AE].

WhiteHeAd A. N., (1932/1947), "Process and Reality," in Symposium in Honor of the Seventieth

Birthday of Alfred North Whitehead, Boston, Harvard University Press; re-edited in Essays in Science and Philosophy, New York, Philosophical Library, 114-19.

WHITEHEAD A. N., (1933), Adventures of Ideas, New York, New American [AI].

WHITEHEAD A. N., (1938), Modes of Thought, New York, Macmillan [MT].

zHок A., (2011), Emergentismo, Pisa, Edizioni ETS.

\section{NOTES}

1. Cf. in particular Lowe (1941a: 113-126), (1949: 267-296), and Schilpp 1941. Also, as far as the Whiteheadian secondary literature is concerned, the interest towards confrontation has never faded away, as the recent monograph by M. Weber shows: cf. Weber 2011.

2. I follow here the classical tripartition of Whitehead's thought worked out by Metz in A Hundred Years of British Philosophy and then taken up by Lowe. Cf. Metz 1938 and Lowe (1941b: 17).

3. Italics mine.

4. As Whitehead himself labels the two authors (SMW: 40, 145).

5. Whitehead is indeed very timely in stressing that there is no mere fact which is by itself neutral. With regard to this, see the whole discussion outlined both in Symbolism, which allows us to understand the distance that separates Whitehead from naïve realism, and some passages of Function of Reason, where the author - although addressing issues of different kind - claims: "Nobody directs attention when there is nothing that he expects to see. The novel observation which comes by chance is a rare accident, and is usually wasted. For it there be no scheme to fit it into, its significance is lost" (FR: 57). 
6. Cf. also SMW: 143: "The scientific materialism and the Cartesian Ego were both challenged at the same moment, one by science and the other by philosophy, as represented by William James with his psychological antecedents; and the double challenge marks the end of a period which lasted for about two hundred and fifty years."

7. My italics. From a subsequent passage one can infer that Whitehead speaks here by constantly keeping James's work in his mind, given that he claims: "It is equally possible to arrive at this organic conception of the world if we start from the fundamental notions of modern physics, instead of, as above from psychology and physiology. In fact by reason of my own studies in mathematics and mathematical physics, I did in fact arrive at myonvictions in this way" (SMW: 153).

8. 8 See also the first lesson of the Modes of Thought, in which Whitehead includes James (alongside Plato, Aristotle and Leibniz) among the "great thinkers [in Western Literature], whose services to civilized thought rest largely upon their achievements in philosophical assemblage." And also his well-known letter to Hartshorne (2nd January 1936), in which the author states: "my belief is that the effective founders of the renascence in American philosophy are Charles Peirce and William James. Of these men, W.J. is the analogue to Plato, and C.P. to Aristotle" (MT: 3). See also Hartshorne (1972: xi).

9. In order to understand the nature of the confrontation and so avoid any kind of misunderstanding, it is useful to preliminarily bring to light a remark by Victor Lowe, one of Whitehead's first critics and his biographer. In an article published in 1949 he points out that the relationship between James and Whitehead ought to be understood more in terms of appreciation and sympathy than in terms of influence in the strict sense, also adding that in 1941 Whitehead, on the occasion of a personal conversation, had specified that "there was no question of James affecting the direction of his thinking"; Lowe (1949: 289). This observation does not undermine the scientific nature of the relevant critical scholarship, even the most recent one (suffice it to consider, with exclusive reference to the year 2011, Weber's monograph and three articles that appeared in the European Journal of Pragmatism and American Philosophy: Weber 2011, Soelch 2011, Stenner 2011, Teixeira 2011); it rather allows to keep a distance be- tween the two thinkers, and therefore a space of originality which makes the confrontation between them even richer and profitable, without having to sacrifice any peculiar element of either in the name of nexuses which are more supposed than given. Therefore, by dissociating myself from a radical interpretation that would frame Whitehead's speculative opus as a systematization of James's ideas (cf. Eisendrath 1971: xiii; Ford 1982: 107), I would like to survey that confrontation which has been advanced in the last years mainly by Weber's and Sinclair's works on the common themes of (epochal) time, of feeling, of consciousness and of religion (cf. Sinclair 2009; Weber $2002,2003,2011$ ), in the hope to provide further contribution to the comparison, concerning the t opic of novelty.

10. 10 The aspects at issue are certainly expression of a tendency 'vers le concret,' to quote what is probably the very first text which puts Whitehead in relation to James; Wahl 1932. Of such a tendency, expressed by the American pragmatism as well as by Whitehead's philosophy - not to mention Husserl's phenomenology, although with a different emphasis - unquestionably partakes also Bergson's reflection. If the relationship of reciprocal respect between the latter and James is well-known, largely ignored is the esteem which Bergson had for Whitehead. In fact, in the years that immediately preceded Whitehead's invitation to teach in the States, Bergson, being asked for advice with regard to the names that might have restituted prestige to Harvard's faculty of philosophy, did not hesitate to define Whitehead as "the best philosopher writing in English"; cf. Lowe (1990: 133).

11. My translation from Italian.

12. The immediacy of experience to which James refers his readers, as indicated by the previous quotations, is starkly different from an understanding of the present as punctual and atomic. Far 
from being a stance assumed in the gnoseological field, such a perspective takes root in the analysis of the proper concept of "experience," so that, on the author's view, the present time in its immediacy already implies a reference to the future. As James states: "The alternative between pragmatism and rationalism, in the shape in which we now have it before us, is no longer a question in the theory of knowledge, it concerns the structure of the universe itself. On the pragmatist side we have only one edition of the universe, unfinished, growing in all sorts of places, especially in the places where thinking beings are at work" (WWJ1: 124).

13. My italics. With the aforementioned claim the retrospective perspective is by no means rejected. As James asserts in another passage of the quoted essays: "Life is in the transitions as much as in the terms connected; often, indeed, it seems to be there more emphatically, as if our spurts and sallies forward were the real firing-line of the battle, were like the thin line of flame advancing across the dry autumnal field which the farmer proceeds to burn. In this line we live prospectively as well as retrospectively. It is 'of' the past, inasmuch as it comes expressly as the past's continuation; it is 'of' the future in so far as the future, when it comes, will have continued it" (WWJ3: 42).

14. Whitehead's perspective - considered in relation to this text - is extremely sympathetic to the pragmatic method, which, leaving aside the rest, is already explicitly evoked in the title (Function of Reason). Such a title directly echoes those arguments worked out by James on consciousness, the latter being understood not as an entity, but as a function, and to the same arguments Whitehead himself devotes some significant pages in Science and the Modern World. Cf. James's Does Consciousness Exist? in WWJ3: 3-19.

15. For a meticulous criticism of the space occupied by 'reason' in Whitehead's philosophy and a comprehensive analysis of the text at issue, see Abbagnano 1961.

16. With regard to this issue, I shall not dwell on the parallelism subsisting between such a definition and that of "education" worked out by Whitehead in 1923 and contained in "The Rhythmic Claims of Freedom and Discipline"; cf. AE: 50 . To such a topic I shall refer the reader to Weber (2011: 15-17).

17. My own translation of Cafaro (1963: 11). On this aspect and on the affinities between the concept of reason according to Whitehead and to American Pragmatism see also Rovatti (1969: 163).

18. In fact, within the framework of the universe, "what looks like stability is a relatively slow process of atrophied decay. The stable universe is slipping away from under us" (FR: 66).

19. Cf. D. R. Griffin was the first who coined this term, precisely on the occasion of a conversation with J. B. Cobb. Cf. Cobb/Griffin 1977.

20. In "Absolutism and Empiricism" James points out that, besides the distinctive bent of absolutism to deny facts, "the one fundamental quarrel Empiricism has with Absolutism is over this repudiation by Absolutism of the personal and aesthetic factor in the construction of philosophy" (WWJ3: 143).

21. 21 With regard to this see above and, among the numerous passages of James's last writings, these synthetic claims taken by Pragmatism: "Pragmatism represents a perfectly familiar attitude in philosophy, the empiricist attitude, but it represents it, as it seems to me, both in a more radical and in a less objectionable form than it has ever yet assumed. A pragmatist turns his back resolutely and once for all upon a lot of inveterate habits dear to professional philosophers. He turns away from abstraction and insufficiency, from verbal solutions, from bad a priori reasons, from fixed principles, closed systems, and pretended absolutes and origins. He turns towards concreteness and adequacy, towards facts, towards action and towards power. That means the empiricist temper regnant, and the rationalist temper sincerely given up" (WWJ1: 51).

22. For an interesting critical analysis on the issue see Schrag (1969: 480-482).

23. My own translation from German. 
24. Although, notably, some passages make room for this interpretation. On the issue see what is stated in WWJ3: 46: "Its [of experience] phases interpenetrate and no points, either of distinction or of identity, can be caught. Pure experience in this state is but another name for feeling or sensation. But the flux of it no sooner comes than it tends to fill itself with emphases, and these salient parts become identified and fixed and abstracted; so that experience now flows as if shot through with adjectives and nouns and prepositions and conjunctions."

25. First italics mine.

26. 26 Also Peirce, in a letter of 1905 addressed to James, criticizes his inaccurate expression of experience, mentions that James tends to "describe it as a process." Cf. CWJ10: 535. Peirce writes: "As for your 'pure experience,' which you expressly say is a feeling, it seems to me ill-named experience, which you describe as a process. But you never mean by experience what I mean, as is evident from your amendment to my doctrine of pragmatism. Experience and an experiential event or perception are, for me, utterly different, experience being the effect which life has produced upon habits. Apparently this is something to which your theory pays little regard, otherwise you could not call a feeling or sensation experience."

27. In other words, the that is not chronologically prior to the what, which we might view as matching our definite daily experience. From within the what, the necessary and specific content of the that, it is always possible to grasp the that, - that is to say: the fact that it (a given thing) is, - and to understand that this aspect overcomes and is not reducible to the content, indicated and expressed in terms of what. Cf. WWJ1: 118: "What we say about reality thus depends on the perspective into which we throw it. The that of it is its own; but the what depends on the which; and the which depends on us. Both the sensational and the relational parts of reality are dumb; they say absolutely nothing about themselves. We it is who have to speak for them."

28. Cf. my own translation of Bonfantini (1972: 118): "Among the thinkers who have influenced Whitehead a central place is held by William James, not only and not so much for his pluralism as for his conception of experience a 'structured lived experience,' dominated by an immanent relationalism, that is, for his anti -Humean and anti-atomistic empiricism."

29. Such a concept, given its opening a window to possible anti-intellectualist or irrational drifts, does not actually find any space in Whitehead, who rather supports, as we will shortly see, a radical form of non naïve realism, defined by critical scholarship "pan-experientialism." In fact, on Whitehead's view, the risk at stake is that of extending - opposite to any dogmatism - the denial of its method to a denial of any type of method, discrediting, as a matter of fact and almost completely, the same function of the philosophical practice. The author states: "Philosophy has been afflicted by the dogmatic fallacy, which is the belief that the principles of its working hypotheses are clear, obvious, and irreformable. Then, as a reaction from this fallacy, it has swayed to the other extreme which is the fallacy of discarding method. Philosophers boast that they uphold no system. They are then a prey to the delusive clarities of detached expressions which it is the very purpose of their science to surmount. Another type of reaction is to assume, often tacitly, that if there can be any intellectual analysis it must proceeded according to some one discarded dogmatic method, and thence to deduce that intellect is intrinsically tied to erroneous fictions. This type is illustrated by the anti-intellectualism of Nietzsche and Bergson, and tinges American Pragmatism" (AI: 287).

30. In fact, these three features are to be referred to a span of time wider than the epistemological writings, in which Whitehead still lingers on attributing to the event the original status as 'process,' describing it first and foremost as 'extension.' Only starting from the second edition of An Enquiry Concerning the Principles of Natural Knowledge the author will explicitly claim, while commenting the first edition dating back to 1919: "The book is dominated by the idea that the relation of extension has a unique preeminence and that everything can be got out of it. During the development of the theme, it gradually became evident that this is not the case, and cogredience had to be introduced. But the true doctrine, that 'process' is the fundamental 
idea, was not in my mind with sufficient emphasis. Extension is derivate from process, and is required by it" (Whitehead 1924: 202).

31. This point is for Whitehead pure abstraction: when should we ever experience a similar instant? Remarkably, the author claims that: "The solution of the difficulty is arrived at by observing that the present is itself a duration, and therefore includes directly perceived timerelation between events contained within it. In other words we put the present on the same footing as the past and the future in respect to the inclusion within it of antecedent and succeeding events, so that past, present and future are in this respect exactly analogous ideas" (AE: 186).

32. With regard to his inquiry on space and time, Whitehead speaks of "uniformity of the texture of experience" (AE: 164).

33. My italics.

34. Cf. Vanzago (2001: 287).

35. My own English translation [italics mine]. From this point of view, various in-depth treatments would be urgently required. I cannot but refer the reader here to other critical studies. I make reference here to a) the 'emotional ground' proper to this new mode of conceiving experience and hence the inclinations and the feelings that forge its inner organization. Cf. Lowe 1941; b) the new way of conceiving subjectivity, as function in the case of James and by way of introduction of the reformed subjectivist principle in Whitehead's case. Cf. Weber (2011: 21-24); Sinclair (2009: 116). With regard to this, suffice it to notice the continuous closeness of the two authors from a methodological point of view. According to James, "the principle of pure experience is also a methodical postulate. Nothing shall be admitted as fact, it says, except what can be experienced at some definite time by some experient; and for every feature of fact ever so experienced, a definite place must be found somewhere in the final system of reality. In other words: Everything real must be experienceable somewhere, and every kind of thing experienced must somewhere be real" (WWJ3: 81), this is perfectly in line with the claim of Whitehead's reformed subjectivist principle, according to which "apart from the experiences of subjects there is nothing, nothing, nothing, bare nothingness" (PR: 167).

36. For an exhaustive account of this term, now usually attached to Whitehead's thought, cf. Griffin 2007.

37. 37 Letter of September 30, 1904 addressed to C. S. Peirce.

38. Whitehead adds in footnote: "Some Problems of Philosophy, Ch. X; my attention was drawn to this passage by its quotation in Religion in the Philosophy of William James, by Professor J. S. Bixler" (PR: 68). With respect to the comparison between the theories of temporality and epochal time in both authors, see also Texteira 2011 and Field 1983.

39. The two reported syntagms are employed by Lowe to describe Whitehead's position. However, I believe that, in support of my thesis, they can equally be adopted for James's position, which shows this complexity and paradoxicality, already at the level of the analysis of experience, with that peculiar oscillation between pure and structured experience analyzed above. Cf. Lowe (1949: 290).

40. Otherwise, the author goes on: "The alternative to this doctrine is a static morphological universe" (PR: 222).

41. Cf. WWJ4: 9: "What do the terms empiricism and rationalism mean? Reduced to their most pregnant difference, empiricism means the habit of explaining wholes by parts, and rationalism means the habit of explaining parts by wholes. Rationalism thus preserves affinities with monism, since wholeness goes with union, while empiricism inclines to pluralistic views."

42. A few lines before, the author affirms: "We can't explain conceptually how genuine novelties can come; but if one did come we could experience that it came" (WWJ7: 73).

43. 43 As the author goes on: "the recognition of this fact of coalescence of next with next in concrete experience, so that all the insulating cuts we make there are artificial products of the 
conceptualizing faculty, is what distinguishes the empiricism which I call 'radical' from the bugaboo empiricism of the traditional rationalist critics, which (rightly or wrongly) is accused of chopping up experience into atomistic sensations, incapable of union with one another until a purely intellectual principle has swooped down upon them from on high and folded them in its own conjunctive categories" (WWJ4: 147).

44. Whitehead's letter to Hartshorne, January 2, 1936, cit. in Lowe (1990: 346) [italics mine].

45. Whitehead (1947: 116). Subsequently, the author points out that "There are these two prevalent alternative doctrines respecting the process apparent in the external world: one, which is Bergson's view, is that the intellect in order to report upon experienced intuition must necessarily introduce an apparatus of concepts which falsify the intuition; the other is that process is somewhat superficial, illusory element in our experience of eternally real, the essentially permanent" (Whitehead 1947: 116).

46. Cf. PR: 222.

47. 47 Cf. Ford 1983.

48. 48 Cf. Zhok (2011: 7).

\section{ABSTRACTS}

The relationship between James and Whitehead has been underlined from the very outset by the critical scholarship on Whitehead, as is testified by the presence of articles that appeared before the author's death. By dissociating myself from the radical interpretation that frames Whitehead's speculative opus as a systematization of James's ideas, I survey that confrontation which has been advanced in the last years (Weber 2002, 2003, 2011, Sinclair 2009) in order to provide further contribution, by tackle the problem of novelty. Precisely, I concentrate on those instances, especially the methodological ones, which are not simply akin, but rather properly shared by the authors. In other words, I focus on those grounding ideas from which they endorse a pluralistic universe, conceived in connection with the problem of novelty. Properly, 1) I analyze the way Whitehead refers to James in his books; 2) I compare the roles they acknowledge to reason, in the nexus with the concept of experience; 3) I show the importance both authors ascribe to the problem of novelty, the main topic involved in their efforts to build up new cosmologies.

\section{AUTHOR}

\section{MARIA REGINA BRIOSCHI}

Università degli Studi di Milano

mariaregina.brioschi[at]unimi.it 